Meta

Journal des traducteurs

Translators' Journal

\title{
The Translation of Irony
}

\section{Marta Mateo}

Volume 40, numéro 1, mars 1995

URI : https://id.erudit.org/iderudit/003595ar

DOI : https://doi.org/10.7202/003595ar

Aller au sommaire du numéro

Éditeur(s)

Les Presses de l'Université de Montréal

ISSN

0026-0452 (imprimé)

1492-1421 (numérique)

Découvrir la revue

Citer cette note

Mateo, M. (1995). The Translation of Irony. Meta, 40(1), 171-178.

https://doi.org/10.7202/003595ar

\section{Résumé de l'article}

L'auteur propose d'abord une définition de l'ironie, puis explore les éléments qui permettent la perception de l'ironie et une classification par types. Elle présente ensuite les facteurs qui rendent facile ou impossible la traduction de cette figure de style. Enfin, l'auteur propose une nouvelle approche pour l'étude de la traduction de l'ironie et le développement d'une méthode descriptive de recherche qui permet de dévoiler les stratégies traductionnelles adoptées dans différentes traductions.
Ce document est protégé par la loi sur le droit d'auteur. L'utilisation des services d’Érudit (y compris la reproduction) est assujettie à sa politique d'utilisation que vous pouvez consulter en ligne.

https://apropos.erudit.org/fr/usagers/politique-dutilisation/ 


\section{THE TRANSLATION OF IRONY}

\section{Resumé}

L'auteur propose d'abord une definision de lironice, puis expose les éléments qui permettent la perception de l'iromic el une classification par types. Elle présente ensuite les facteurs qui rendent facile ou impossshle la traduction de cretse figure de sryle. Enfin. l'auseur propose une nouvelle appresche pour l'situde de la traduction de lironie : le développentent d'une méthode descriptive de recherche qui permet de dévouler les stratégies rraductionnelles adopteses dans differentes sroductloms

\section{A BRIFF STUDY OF IRONY}

The first problem that arises when studying irony is that of its definition. Nowadays, most critics agree that the old concept of irony as "saying one thing and 
meaning another" is no longer a comprehensive or accurate description of the multifarious and complex lechniques that writers use to create irony. On the other hand. irony, and in panticular verbal irony, is not something that can be recognied hy a fixed set of linguistic or stylistic features: there is no recognizable ironic tone or style. Irony depends on context. Just as there are no words or expressions which are humorous per se but by reason of their semantic or syntaclic use in a contexl and which, as Walter Nash puts 1t, will have to the defined "extrinsically" by their contexlual linkages and semantic relationships, so irony depends on context since it springs from the relationships of a word. expression or aclion with the whole text or situation. Irony is a pragmatic catcegory which activates "an endless series of subversive interpretations." (Muecke 1982: 31), as a product of the contexlual selting of a character's words or actions. The double interpretation of irony is therefore different from that of wordplay. which is the proxicuet if at linguistic structure and it is a question of different messn. ings rather than inferpre'tolionts.

Muecke identufies threc ensential elements for irony (Muecke 1969: 14-20): a) a (wo-slorey phenomenon: a lower kevel, the situation as it appears to the victim or as it is cleseptively presented hy the iro. nist, and an upper level, the situation as It appears to the observer or the iromist ; b) some apposition between the two: contraditton. incongruity,... : () "innecence": a victim unaware of the existence of an upper level, or an ironist pretending he is unaware. The first element relates jrony of humour smete it recalls what Nash defines as the complex structure of humour, consisting of a "superstructure" the formulate structure of the joke --, and a "substructure" . the underlying context that the reader/listener needs to hatve in his grasp (Nash 198.5: 31). The opposition belween the two levels has to be wrapmed up in a fecling of ambiguity, since it is a characteristic feature of irony that both reality and appearance should be presented as true. The matin focess of irony is the relationshup between the lwo interpretations intended, rather than the content itself (Tanaka 1974: 46). It is actually this feeling of contradiction between the iwo levels that dislinguishes romy from sarcasm: irony "mal-coxtes" (Nash 1985: 1.52-153), it misrepresents the real conlent of the message so that the contradiction must be assumed as nomal, whereas a sareastic statement is ostensibly sincere and provokes no feeling of contradiction at all. The third element, real or pretended innocence, relates irony 10 drama, which, whether in its tragic or in its comic form, has hlindness of char acters as a basic feature. As can the obeerved, all three clements peint to the significance of context or the pragmatic cuntent in the creation af irony.

The facl that irony "mal-conle"s" or that it presents two opposed realities as trut does not imply that its purpose should te to dective: unlike deception. in which the contrast between the two levels is intended wo conceal a real meaning, irony is meint to be understood. and the resognition of the real meanng. or rather, of the facil that there is a real meaning different from what is being proposed. is essential for the full realization of irony

Just as in any type of humour, a failure to signal the intention to joke may compromise laughter and the necessary quickness of response, so irony that is not explicitly stated may result in a wrong inference from the reader or hearer. The ironist doets not always need to signal hos intention to ironize: the topic itself or the values shared by both ironist and victum may imply he must to ironic. To put It differently, the signals may be in the context (the common values inform the vetim that the ironist "cannot be speaking in earnes"). or they may accompany the text (gestures....) or be part of the text itself. This is closely related to the factors that affect the correct/incorrect perception of irony, which will be of great signicance for its translation, as will be examined later. According 10 Muecke 1 197.3b: 38), these factors are: the Sender's capacity for mony and the Recieiver's personal sensitivity (o) irony, the communtly rules relating to irony of toth Sender and Receiver and the degree of conncidence between the two sets of rules. the Receiver's knowledge of the Sender and of his ironical lechnique, the Receiver's familiarty with the rules of the Sender's upech community and, finally, the probabilIty of ironic intention and of assumption of irony. Not only individual qualities but also the rules of conversation affect thes perception: Grices" "Cooperative Principle" in conversation maty to broken in order to creale humour or 10 signal an mtention 10 be ironic. According of this principle, there is a tacit acceptance hy the participants in a conversation to supply sufficient and appropriate information (a maxim Grice calls Quantity), to make contributions that are true and nol (o) saly anything that one believes is false (Quality). to be relevant (Relation). and to be brief and orderly and to avoid obscurily and ambiguity (Manner). The hearer's communicative competence enables him to perceive when the speaker is breaking these maxims and being ironic.

If neither the topic nor the common values are indicative of an ironic intention, or if the factors operating on Sender and Receiver are different, then the uronist will resort to other signals, usually as few as possible, such as the contradiction between expression and content fo.g a formal register in an informal context), between various elements at the level of contem (r.g. logical contradictions), between various slements at the level of expression (d'.s. stylistic exaggerations), between linguistic systems, or between prowodic and other linguistic features (use of intonatiom). (Muecke 1973a: 16.3-164: 197.3b: 41) According to Searle and Austin, words and sentences are speech as ts with a lincuriomary force (a propositomal meaning), an illocurtoplary force (they may constitute a question. a command...). and a perlociationary force (they intend to cause a reaction on the hearer). An ironist may revert the pragmatic significance of a sentence and interpret the illecutionary force of a speech att wrongly (a's. laking a question as an assertion) 
All these are ways for the ironist both to be ironic and to signal his intention, both to code his irony and to help his victim decode it, since although there must always be ambiguity in the recognition of irony - as opposed to sarcasm --, irony, as explained above, is ultimately intended to be interpreted correctly.

Irony may therefore spring from several factors. and it lends itself to classification into different types. A first division would be that of intentional vs. unintentional irony, which some critics call linguistic and dramatic, or instrumensul and observable, the difference between the two lying in whether a speaker (the ironist) has the intention to make an utterance for (wo audiences (i.e. intentional irony. which is therefore mainly verbal) or whether a person perceives a contradiction in some situation or series of events and makes judgements about it, while there is another person who is completely unaware of it (i.e. unintentional or aramaric irony). Therefore, while intentional irony is being communicated, unintentional irony exists already in the situation. However, this existence has to be actualized by the ironist. and we may claim that in plays this type of irony is also being communicated. t.e. there is a playwright presenting an ironic situation, and the irony thus turns out to be intentional. Actually, as both Muecke and Tanaka point out, in literary texts the distinction between intentional and unintentional irony is not clear-cut, particularly since the author's point of view is not always obvious and easy to assess.

Muecke distinguishes four modes of irony according to the pan played by the ironist (Muecke 1969 61-9.3): impersonal irony, in which we are unaware of the ironist, and the irony lies in what he says rather than in the fact that it is a particular person saying it: self-disparaying irony. in which the ironist presents himself as ignorant and is a guide to our judgement: angenu irony, in which the ironist wathdraws, using a character, an ingénu. for his srony: and drumatized irony, in which the ironist withdraws completely and presents an ironic situation.

Impersonal irony offers a wide range of differen techniques: praising in order to blame. blaming in order to praise. pretended agreement with the victim. pretended advice or encouragement to the victim. rhetorical questions, pretended doubt, pretended error or ignorance. innuendo and insinuation, irony by analogy. ambiguity. pretended omission of censure. pre. tended attack upon the victim 's upponent, pretended defence of the victum, misrepresentation or false statement, intemal contradiction, fallacious reasoning. stylistic contradiction and parody. understatement, overstatement and displaying the latently ironic (Muecke 1969: 61-87)

Muecke mentions impersonal. self-disparaging and ingenu irony as characteristic of novels, and dramaticed irony as. obviously, typical of plays. However, although from the playwright's point of view there would only be dramatized irony, we may claim that among the characters there may also be cases of impersonal irony: one character may be ironical and use irony as a weapon in the same way as a novelist can. Irony is actually much more complex and sharper in drama that in any other type of text: not only can characters speak ironically of one another and to one another, but also a character's words may refer both to the situation as it appears to him and to the situation as it really is, he himself being unaware of this. And, although a character can never be taken to speak absolutely on behalf of the writer, the principle of tex. tual embedding may always apply in drama, that is, the utterances of a character may the embedded in the text of another speaker, namely the playwright or even the actor, thus resulting in a complex type of irony which would involve not only the characters of the play but also extemal elements such as the actors. the playwright and even the audience itself. This is actually the lype of irony that springs from those injokes actors and playwrights used to the so fond of in the 18 th century. Nearly every theatrical element can he incorporated into the play to create an ironic situa. tion: the performance and rehearsal of the play (play-within-the-play), the playwright or director, the dramatic conventions of the time, the actor. the audience. etc. The power of dramatic irony is also added to by the situation of all the characters at a given moment and by the relationship between them. Finally. a dramatic performance introduces a whole range of gestures, mime, intonation and comic spectacle which enhances the irony that arises either from the characters' utterances or actuons and which places them in a much more complex context.

On the other hand, all types of irony have a dramatic component: the conspiracy element, which is common to other types of humour as well. There is always some need for cooperation between speaker and listener in humour. To quote $M$. Vasconcellos, "humor makes exaggerated claims on the relationship between speaker and listener; it is in fact the largerthan-life essence of that partnership." (1986: 145) In the case of irony, this cooperation becomes conspiracy. Nash proposes a formula for some types of humour, which actually exemplifies what happens not only in dramatic humour but also, I might say. in all types of irony:

(E. "Rt ( " R)

E: executani (author, "I"....):

Et: executant within the text (the persona who speaks for the author);

$R t$ : respondent within the text (persona controlled by EI and making responses shared or disclaimed by $R$ ):

R: Respondent (reader, as observer and censor). (Nash 1985: 19.20)

The outside respondent--whether reader, audience or character-is allowed into the joke. while the respondent within the text (which may be another character or a reader unaware of the ironist's real meaning). is left in the dark. This is actually how irony works and it is that conspiracy between the 
speaker and the privileged receiver that provokes the sense of superiority and detachment characteristic of irony and, ultimately, of any type of comic pleasure.

\section{THE, TRANSLATION OF IRONY}

The first conclusion that may be drawn from what scholars have written absut the translation of irony so far is that most of them concentrate on the difficulty or ease of this lask. Indeed. most studies of the translation of humour in general are devoled to this question alone. They therefore usually establish a gradation of difficulty and claim that the more humour relies on linguistic aspects ( $f^{\prime}, g$. puns) the more likely we shall have to face untranslatability. Humour based on irony or on reversal of situation or tone will be more widely translatable. Cultural jokes need cultural familiarily or contact hetween the nations concerned in their translation and will be more difficult to translate when the linguistic and the cultural component are very closely related. Finally. universal jokes will be the easiest to translate. if they do exist.

Humour and irony are often linked to poetry and works of an, as they require the subjectivity, balance and striking formal structures characteristic of pectic language. It is therefore not surprising that the translation of humour should be linked to that of pextry in numerous analyses by critics, since the formal aspects are an integral part of beth types of texts. The link is also estathlished on the basss of the difficulty of both tasks: "When it comes lo translating humour. the operation proves to be as desperatc as that of translating poetry." (D)ot 1989: 84)

Another aspect that is generally highlighted is the problem of contex1, which plays an important role in the creation of irony, as has been underlined atove. There is always the need for background knowledge of a socio-cultural type of apprecialc irony. particularly in the case of satire and allusion. The ranslation of humour and satire depends on the proximity of cultures: the more distant the culture, the more difficult the understanding of humour will he. And even if satire is understed, there may not to the same mechanisms to create it in the larget language, or the new culture may just not find it funny, since for satire (o) he humorous it requires some sympathy after the criti. cism on the part of the reader/listener. It is no wonder then that publishers should generally be wary of translations of satire on the grounds that it is "f(x) local" and that it would need recrealom, a lechnique that some translators aboolutely refuse to adopt and that translation critics often condemn

A conception of translation as a process of transporting "xelle" dex not account for the intreate process of humour translation since "sense" in humour. and particularly in irony, has a much more complex nature, which includes the speaker's intentions, the hackground knowledge of speaker and listener, the assumptions and presuppositions implicit in the text, the connotations of each word, etc. Furthermore, it is not sense alone that constitutes the core of a humorous or ironic statement or situation: the form is also very important, as was mentioned above. In a generative semantics approakch, (wo sentences with the "same" meaning would have the same tree. But irony and humour may simply spring from an alteration in the usual syntactic order of a sentence, from the chosce of an unusual collocation or. indeed. from the very use of a certain word. On the other hand, a linguistic approach is not sufficient either since "humour is an cocurrence in a sexial play" and "it characterises the interaction of persons in situations in cultures." (Nash I985: 12$)$

Most critics agrec that the translator must try to keep the original ambiguity. tone or style whenever they are significant in the source text. When that is not possible. they opt for an "equivalent effect" translation: taking the idea or the intention of the original humorous messige and adapting it to the target culture in order to provoke an equivalent response in the new reader. As has heell argued recently, the problem with the theories based on "equivalent effect" is that effect can only te measured or predicted by means of one's personal intuition: "in the absence of any objec. live hasis of assessment, larget language reader reaction is no more predictable than source language reacler reaction is measurable, and the shift of empha sis away from the text to hypothetical reception aspects allows unrestricted leeway for any desired bias or distortion." (Hrotherton s.d.: 37, quoted by Delabastita 19(6): 6.3)

What most crits's seem to be doing then is suggesting whit the toist way to translate humour really is. what should and should not te done, keeping the question of translatability always in mind: although one cannot be completely faithful, there is no need 10 change what is easily translatable: the Iransiator should adapt to Tl. culture when there is an equivalemt: one should not explain the irony (or the joke) since explanation destroys humour; one should concentrate on the essence of the joke (e.g. in lingustic jokes. the kind of relationship established between (wo) meanings, between a cerrain style and a content. etc.) and then keep that essence adaptung it to TL conventions even if one changes the specific meaning or facts; one thould concentrate on the effect of the joke on the receiver, etc. The purpose of this paper is not that of questioning the validity of these recommendations. However, I would like (o) remark on the fact that all these rcholars appear to be interested only in the essence of the source texl. and they reduce the yues Itoin at humour tramslation to the rendering of that essence - whether it is defficult, whether it is at all possible or to the absence of orony or humour in a specific target kext. This approach is not sufficient in explain the complex nature of the translation of irony and it does not provide us with any mether for its analysis.

I would therefore like of encourage a new approach and suggest the development of descriptive research, which may not be valid by itself but which 
may at least complement the other approaches. With a limited corpus of English comedies and their Iranslations into Spanish, we may study which strategies Iranslators have adopted when translating irony. whether they have been trying to be faithful to the source text at the expense of humour, or else whether they have managed to keep the irony introducing some significant changes, if they have used any editorial techniques to support a translational solution to a ST translation problem. which conventions have prevailed, etc. We may thus deduce the different points of view adopted by translators, which will, hopefully. point towards a poetics of translation.

I have decided on comedies for my corpus of study because of the complex nature of irony in this type of text, which can always count on the performance to enhance the irony in the text. The comedies studied, however, rely on verbal irony a great deal too, so that they offer not only instances of dramatic irony but also of all the different types of "impersonal" irony on the pan of the characters

The following is a possibic list of strategies which has been drawn from the comedies examined. The terms that identify the type of irony have been taken from Muecke's classification (1969). When the irony springs only from a single word or expression in a spech, the relevant words have been highlighted in italics:

1. ST irony becomes TT irony with literal translation.

\section{Pralsing in order to blame.}

Lady Bracknell. "The whole theory of modern education is radically unsound. Fortunately in England. at any rate. education produces no effect whatsoever." (The Imporfance of Being Earnest, I 497-50())

(1952): "Todas las teorías modemas de la educación son enfermisas. Afortunadamente, la educación no produce ningún efecto en Inglaterra."

(1975): "Lal teoria de la educación moderna es integra y radicalmente falsa. Afortunadamente, en Inglaterra al menos, la educación no produce el menor efecto."

\section{Internal contradiction.}

Lady Bracknell. "London society is full of women of the very highest birth who have. of their own free choice, remained thirty-five for years. Lady Dumbleton is an instance in point. To my own knowledge she has been thiry-five ever since she arrived at the age of forty, which was many years ago now." (The Importance of Being Earnest. III 260-26.5) The malter-of-fact tone of this speech prevents it from being "irony displayed" or "innuendo" with ironic tone. Lady Bracknell is being ironic in a much subtler way. pretending she actually believes what is so obviously illogical. This would nevertheless depend on the actress.

(1952): "La mejor sociedad de Londres está llena de mujeres de elevada cuna que, por su libre decisión. se han quedado en los treinta y cinco. Lady Dumbleton. por ejemplo. Que yo recuerde, ha venido teniendo Ireinta y cinco desde que cumplió los cuarenta, hace ya bastantes años."

(1975): "La sociedad londinense está llena de damas de elevadisima alcurnia que, por su propia elección. se han quedado en los treinta y cinco. lady Dumbleton es un caso de éstos. por ejemplo. Que yo sepa, ha tenido treinta y cinco años desde que cumplió los cuarenta, hace ya muchos años."

\section{Fallacious reasoning.}

Cecily. "Oh, yes. Dr. Chasuble is a most leamed man. He has never written a single book, so you can imagine how much he knows." (The Importance of Being Earnert, II 536-538)

(1952): “"Por supuesio! El doctor Chasuble es un hombre cultísimo. No ha escrito nunca ningún libro. Ya puedes imaginane lo que sabe."

(1975): " "Oh. sf! El doxtor Casulla es un hombre doctísimo. No ha escrito jamás un solo libro; así que puede usted figurarse lo mucho que sabe."

2. ST irony becomes TT irony with "equivalent effect" translation.

\section{Innuendo.}

Mrs. Candour. "[...] a cenain widow in the next street had got rid of her Dropsy and recover'd her shape in a most surprising manner." (The Sithool for Srandal, 1 i 20.3-204)

(1955): "ciena viuda, de una calle próxima, se habia visto libre de su hidropesía y habia vuel(") a sus andarizas del moxdo más sorprendente."

3. ST irony becomes $\mathrm{TT}$ irony through means different from those used in ST (e.g. verbal irony becomes kinetic irony, the use of intonation is replaced by lexical or grammatical units, etc.).

\section{Dramatic irony.}

4th Avocatore. "We have done ill, by a public officer to send for (Mosca). if he be heir."

3rd. Avoc. "'Tis true: he is a man. of great state. now left."

4ih Avoc. "Go you. and learn his name: and say the court entreats his presence, here: but. to the clearing of some few doubss." (Volpone, $V \times 36-42$ )

(1952): these speeches have been deleted, but the irony on the different treatment afforded to Mosca once they have learnt he is now a man of wealth is maintained in the fact that, when Mosca arrives, the avocatori address him with greal deference. This would probably be emphasized on the stage by means of bows and an extremely polite tone.

4. ST irony is enhanced in TT with some word/ expression.

\section{Drametic Irony.}

Corvino (to his wife). "God's precious, this is scurvy: "tis very scurvy: and you are-" $[\ldots]$ "An errant 
Iocust, by heaven a locuste. Whore, |... |' (Volpome, Ill vii $116-118$ ) The irony lies in the fact that it is actually him that is forcing his wife, who ahsolutely refuses to do so, to lie with Volpone in order to gan his favour and eventually his legacy. The irony is in fact twofold. as Corvino had been ridiculously and unreasonably jealous in all the previous sienes.

(1980): "Dion trendito, esto es un deshonor, un puro deshonor, y tú eres..." "I/na nute de langosa. por el cielo, una devoradora!... Puta. $|.$.$| " the irony is$ enhanced by the use of the word "deshonor" in the translation.

5. ST ironic innuendo becomes more restricted and explicit in $\mathrm{T}^{\mathrm{T}} \mathrm{T}$.

\section{Innuendo.}

Mrs. Candour. "Poor dear (iirl- who knows what her situstion may be!" (The Scherel for Scandal, I i 326 )

(1955): "PPohre niña. quién sabe en qué aprieless se encuentra!"

6. ST Irony becomes TT sarcasm fcriticism is overt now, no feeling of contradiction at all).

\section{Dramatic irony.}

The subile ironic allusion to the influence of at defendant's social status and wealth on judges" attitudes and decisions. illustrated in strategy number 3 with an example taken from Lilpome $(V \times 36-42)$ wits replaced in the 1929 translation with overt and bitter satire on judges. The translator has recreated the whole act and the weight has shifted now from Volpone's and Moscia s ambition and covetousness to the corruption of judges: the magistrates have now been offered money and presents 10 affirm what is evidently true and, like all the other characters in the play, they are all interested in Volpone ' legacy

\section{Understatement.}

IAlgernon. "The truth is rarely pure and never simple. Modern life would the very tedioun if it were either, and modem literature a complete impossibility!"

Jack. "That wouldn't the at all a bad thing." (The Importance of Being Earnest, $1215-216)$

(19.52): Jack. "Mira. |en | eso iríamos ganando."

7. The hidden meaning of ST irony comes to the surface in TT. No irony in TT therefore.

\section{Understatement.}

Volpone. "|... $\mid$ women and men, of every sex and age, that bring me presents, send me plate, coin. jewels. with hope. that when I die (which they expect each greedy minute) it shall then return lenfold upon them. [...] All whech I suffor. playing with the ir hopes." (Volpone I i 77.8.5)

(1952): " Como goro al jugar con sus esperanzas...!" With the shift from "suffer" to "goen", Volpone now states what he feels clearly and with no irony whatsocever.
8. ST ironic ambiguity has only one of the two meanings translated in TT. No double entendre or ambiguity in TT therefore.

\section{Innuendo.}

Mrs. Candour's innuendo on "dropsy" and "recover'd her shape" illustrated in srategy number 2 (The School for Sicundal, I , 203-2(14) has heen translated as: "[una de nuestras ammgall fue a curarse de una hidropesia. y en más, lo logró y volvió a Madrid per. fectamene buena." ( $|86|)$ : and "ciera viuda de la calle próx ma ha vido curada de su hidropesia. resos. hrander la salusd de la manera más sorprendente." $11868)$ Both translators have chosen to translate "shape" only in its ense of "health", discegarding the other piquant sense of the lady having possibly been pregnant and having recovered her usual figure now.

9. ST irony replaced by a "ynonym" in TT with no two pussible interpretations.

\section{Innuendo.}

Mosca. "He knows the state of [ Volpone's] body, what it is: that nought can warn his bloced $[\ldots \mid$ nor any incantation raise his spirtt: a long forgetfulness hath seised that part." (lislpone. II vi 64-6h) (trying to persuade Corvino to make his wife lic with Volpone since he is only a decrepit old man on his deathbed. A physician has already offered hos daughter. Mosca says. 1

(1929): "No ignora su estado fisico. nada peligroso para la honestidad de su hija, me el poder de captación que una muchacha joven y bien adiestrada puede ejercer sobre el débil ámmo de un enfermo."

\section{0. $\mathrm{ST}$ irony explained in formote in $\mathrm{TT}$.}

\section{Pretended defence of victim.}

Sir Oliver. "Yet thet has a string of charitable Sentiments I suppose at his Fingers' Einds!-"

Rowley. "Or rather at his Tengue's end Sir Oliverfor I believe there as no ventiment He has more faith in than that 'Charity begins at Home'."

Sir ()liver. "And his I presume in of that domestic sort which never stiss athroad at all." (The Sicheol for Sicundul, $\vee$ i 27-32)

The $(1868)$ translator has translated the first idiom literally but has felt the need to explain Sir Oliver's irony an a fextenote:

Sir Oliverio. "Según creo, hay una cuerdia sentimental que vibra en la punta de cada uno de sus dedos."

Rowley. "Sí: y su máxima favorita es esta: 'La caridad bien ordenadat empiera por uno mismo:" a) $f(x)$ tnote)

Sir Oliverio. "Pues presumes que la suya es una caridad sedentaria que no pasa de ćl a nadic."

"al El proverhio ingles dice asi: '( 'harity begins at home'. 'La caridad comen/a en casa'. Sir Oliverio responde que lat caridad de José es de una especie sedentaria, que mo sale a la calle". Ha sido menester alterar algo cl fexto, conservando el sentido." 
II. ST irony has literal translation with no irony in TT.

Parody.

Jack. "Miss Candew's family solicitors are Messrs. Markby, Markby and Markby." (The Importance of Being Earness. III 1.39-140). There is parody on English lawyers' practices, which were usually formed by fathers and sons. Both the 1952 and the 1975 translations have rendered it literally as "Markby, Markby y Markby": there is humour in the repetition but no social allusion now.

\section{Ironic ST completely deleted in TT}

\section{Innuendo.}

Mosca's speech with innuendo on "that part" mentioned in strategy number 9 from volpone. Il vi 64-66 has been deleted in the 1952 translation, which was an adaptation for the stage. performed at the time of firm censorship from the Spanish authorities.

\section{Analogy and ambiguity.}

Lady Bracknell. "Her unhappy father is $|. .$.$| under$ the impression that [Gwendolen] is attending a more Ihan usually lengthy lecture by the University Extension Scheme on the Influence of a permanent income on Thought." (The Imporlance of Being Earnest. III 77-80). There is double irony here: analogy with the pedantic titles of University Extension lectures and the suggestion that people with high incomes do not have to think and therefore do not think. This speech has been deleted in the 1952 translation. which seems to have removed all culturespecific references.

\section{No irony in ST becomes irony in TT.}

Chasuble. "Charity, dear Miss Prism, charity! None of us are perfect; I myself am peculiarly susceptible to draughts." (The Importance of Being Earnest. II 234-235). The comedy springs from the incongruity in Dr. Chasuble's comparison: he is talking about Emest, who is supposed to have died, and referring to morals, virtues and vices, which he goes on $10 \mathrm{com}$. pare with a physical "weakness" he cannot be responsible for. The 1975 translator has rendered that sentence as: "Caridad, mi querida miss Prism, caridad. Ninguno de nosotros es perfecto. Yo mismo tengo una dehilidad especial por el juego de las damas." By interpreting "draughts" as "checkers" and therefore rendering it as "juego de las damas" he has created a spicy pun. since that word has two meanings in Spanish ("draughts" - the game - and "ladies"), which results in dramatic irony as it is a priest that may be surreptitiously saying he is very susceptible to the game of ladies.

Irony belongs to the pragmatic level of a text, i.e it is very closely linked to context. although it is also dependent on form. like all types of humour. Some translators choose to render the semantic content of an ironic statement or situation, rather than its overall meaning. namely its irony. Others will focus on the pragmatic value of the text, and sacrifice the specific semantic content. Sometimes translators manage to render both. In any case, they will always be determined by the type of text, by the translational, cultural and social conventions of their time, the type of receiver they have in mind, the medium that has been chosen for their translation. the values relating to irony in the target community. etc. All these factors affect the correct communication and perception of irony between two speakers of any given language and obviously also between two "speakers" of two different languages. Both speakers, or rather, both cultures will have to be. at any rate. "ready to play" for irony to be transposed successfully.

\section{MARTA MATEO \\ Universidad de Oviedo, Oviedo. Spain}

\section{REFERENCES}

BALLARD, M. (1989): "Effets d'humour, ambigulite et didactique de la traduction", Laurian. A.-M. \& Nilsen, D.L.F. (Eds.), Meta, 34-1, pp. 20-25.

CHAPMAN \& FOOT (Eds.) (1977): Iis a Funny Thing. Humour, Oxford. Pergamon.

DAWSON, T. (1987): "The Dandy in The Picture of Dorian Gray: Towards an Archetypal Theory of Wit", Hermans, Th. \& Klein. H., Comedy. Special issue of New Comparison, $n$. 3, pp. 133-142.

DELABASTITA, D. (1990): "There's a Double Tongue." An Investigation into the Translation of Shakespeare's Wordplay. PhD. dissertation. Leuven.

DIOT, R. (1989) : "Humor for Intellectuals: $C$ an it Be Exported and Translated"', Laurian, A.-M. \& Nilsen, D.L.F. (Eds.), Mera, 34-1, pp. 84-87.

EASTHOPE. A. (1987): "Jokes and Ideology: "The Frogs' and 'The Earnest '". Hermans. Th. \& Klein. H.. Comedy. Special issue of New' Comparison. $n^{\circ}$ 3. pp. $117+132$

GOLDSTEIN, J. H. (1977) : "Cross Cultural Research: Humour Here and There". Chapman \& Foot (Eds.). Itis a Funny Thing. Humour. Oxford. Pergamon. pp. 167-174.

HERMANS. Th. \& KLEIN. H. (1987): Comedy, Special issue of New Comparison, $n^{\circ} 3$.

LANDHEER. R. (1989): "L'ambiguiité: un defi iraduclologique", Laurian, A.-M. \& Nilsen, D.L.F. (Eds.), Mefa, 34-1, pp. 33-43.

LAURIAN. A.-M. \& NILSEN. D.L.F. (Eds.) (1989): Humour el tradurtion. Humor and Translation. Special issue of Me'a, 34-1.

LAURIAN, A.-M. (1989): "Humour et traduction au contact des cultures", Laurian, A.-M. \& Nilsen. D.L.F. (Eds.), Mera, 34-1. pp. 5-14.

LEIBOLD, A. (1989): "The Translation of Humor: Who Says it Can't Be Done?". Laurian. A.-M. \& Nilsen. D.L.F. (Eds.), Mera. 34-1.pp. 1(99-111. 


\section{ROSS: SEMANTIC DICTIONAAY FOR TEXT UNDERSTANDING AND SUMMARIZATION*}

\section{RESUME}

Le dicfoumbire sémantique russe' à resage génciral (ROSS) est un ouril pour lanalyse siman"laue el informafionnelle de tout te te rasse colverent lat serwelure de ROSS reflete la philosophice et les niveana de représemation adoptés

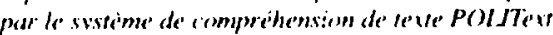

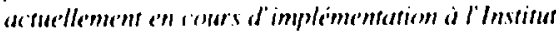

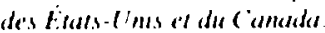

\section{THF PURPOSE OF ROSS}

The Russian general-purpose semantic dictionary, ROSS, is a tool for the semantic (both linguistic and informational) analysis of texts. The rich semantic information contained in the dictionary makes possihle lecal (within one phrase) semantic interpretation as well in the semantic analysis of coherent texis. Some cones of the dectionary provide the powsibility of logico-situational antlysis of a 1 ext and a link to different domains.

The present version of ROSS is designed. firstly. to construct a base of textual facts (BTF) for a given collection of Russian texts. The vocabulary of the the present version is based on communications about political events. The procedure proposed for BTI: construction (Leontyeva 1992) enables any user i1) form an individual BTF ordering the desired degrec of compression of the mitial content. Secondly, the dictoonary is to ensure multi-language, above all. Russian-to-Inghlush. knowledge hased machine translation (KBMT) (sec Johusenr. King and IRe Tombe 1985: Nirenburg 1989: Papaqaai] 1986).

Though similar in many aspects to dictionaries with rech eemantic data belonging to some $\mathrm{MT}$ 